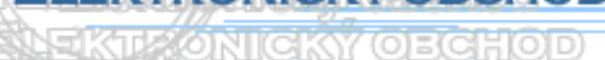

\title{
E-MAIL MARKETING A MOŽNOSTI JEHO VYUŽITIA
}

\author{
Radovan Madleňák*
}

\section{1. Úvod}

E-mailový marketing je pomerne nový, ale momentálne najrýchlejšie sa rozvíjajúci prostriedok internetového marketingu. E-mailový marketing je možné definovat' ako formu direct marktingu, tj. priameho marketingu, ktorý používa elektronickú poštu ako komerčný komunikačný prostriedok. V podstate $\mathrm{v}$ tom najširšom chápaní, môže byt' každý e-mail, ktorý bol poslaný pre potenciálneho alebo aktuálneho zákazníka, považovaný za e-mail marketing.

\section{Direct marketing}

Tvorí oblast' marketingu a je jednou z metód marketingovej práce so zákazníkom. Jeho špecifikom je interaktívnost' a meratel’nost' odozvy u zákazníkov. Spočíva v adresnom oslovovaní zákazníkov, čím je možné dosiahnut' pomerne silnú spätnú väzbu [4]. K základným nástrojom direct marketingu patrí:

- telefonovanie (telemarketing)

- direct mailing, ktorý sa delí na:

o klasický mailing,

o e-mailing (tj. elektronické komunikovanie, e-mail marketing).

Telemarketing predstavuje priame telefonické kontaktovanie vybranej skupiny firiem, či osôb a prináša bezprostredné efekty vo forme uzatvorenia obchodu, dohodnutia schôdzky, alebo zistenia d'alších informácií dôležitých pre obchod a marketing [1].

Klasický mailing spočíva $\mathrm{v}$ priamom zasielaní poštovných zásielok (direct mail) a je vhodný prakticky vo všetkých typoch podnikania. Klasický mailing je možné využit' napríklad pri:

- zavedení nového výrobku alebo služby na trh a informovaní vlastných zákazníkov,

- podpore predaja,

- organizovaní sút'aží pre zákazníkov, a pod.

E-mailing je jedna zo služieb spadajúcich do komplexnej podpory priameho marketingu zákazníkov. Metóda hromadného rozosielania e-mailových správ slúži ako doplnok, alebo alternatíva k telefonickému oslovovaniu, ktorá však môže byt' považovaná za neželané zasahovanie do súkromia alebo obt'ažovanie (SPAM). Zasielanie reklamy touto formou je však paradoxne považovaný za oblúbený spôsob propagácie. Prieskum DMA

\footnotetext{
* Ing. Radovan Madleňák, PhD., Katedra spojov, Fakulta prevádzky a ekonomiky dopravy a spojov, Žilinská univerzita v Žiline, Univerzitná 1, 01026 Žilina, Slovenská republika, tel.: +421/41/5133124, fax: $+421 / 41 / 5655615$, e-mail: Radovan.Madlenak@fpedas.uniza.sk
} 
(Direct marketing association) v USA ukazuje, že použitie e-mail marketingu má lepšiu návratnost' investícií (ROI - Return on Investment) ako direct mail a telemarketing.

E-mailový marketing možno chápat' ako najjednoduchší spôsob komunikácie so zákazníkmi, spotrebitel'mi alebo obchodnými partnermi, ktorý využíva niektoré formy zasielania e-mailových správ [2]. Jeho hlavnými prednost’ami je:

- rýchlost' - správy sú rozoslané a doručené adresátom behom niekol'kých minút,

- dobrá meratel'nost' úspešnosti mailingovej kampane,

- nízke náklady v porovnaní s klasickým „, papierovým“ mailingom,

- aktuálnost' informácií a možnost' využitia spätnej väzby,

- časovanie odosielania kampane.

\section{Ciele e-mailového marketingu}

Primárnym ciel'om e-mailového marketingu je informovat' užívatel'a a upútat' jeho pozornost'. Pomocou e-mailového marketingu je možné budovat' dlhodobý vzt'ah s užívatel'om, získat' si jeho dôveru. Pokial' sú ponúkané informácie hodnotné, užívatel' si na ne zvykne a bude ich rád využívat' z dôvodu jednoduchosti prístupu a vysokú efektivitu.

Sekundárnym ciel'om je naviest' užívatel'a $\boldsymbol{k}$ určitej akcii. Môže to byt' návšteva internetovej prezentácie s podrobnými informáciami, realizácia nákupu alebo zvýšenie dopytu, či získanie marketingových dát pre d'alšie spracovanie [6].

E-mailový marketing môže byt' efektívnym nástrojom pre predaj alebo získavanie spätnej väzby od užívatel'a, pričom sa skôr používa na posilňovanie lojality existujúcich návštevníkov firemného webu, než na získavanie nových návštevníkov.

\section{Systémy e-mailového marketingu}

Pri e-mailovom marketingu existujú dve formy ako oslovit' užívatel'a. Jedná sa o systém:

- OPT-IN

- OPT-OUT

\subsection{Systém OPT-IN}

Princíp OPT-IN spočíva v tom, že najskôr musí zasielatel' určitej formy reklamného emailu získat' súhlas od uživatel'a, ktorého hodlá oslovit' takouto formou. Až potom môže niečo poslat'.

V praxi predstavuje získanie takéhoto súhlasu (povolenia) rozhodnutie užívatel'a poskytnút' svoju e-mailovú adresu určitej spoločnosti, web stránke alebo jednotlivcovi.

Užívatel' môže pri deklarovaní súhlasu určit' oblast' svojho osobného záujmu alebo stanovit' typy e-mailov, ktoré chce dostat' od odosielatel'a. Rozlišujú sa dva druhy prihlasovanie a to:

- Jednoduché prihlásenie - je najdostupnejší a bežne používaný spôsob získavania emailových adries a povolení. Je možné ho vytvorit’ prostredníctvom pozývania návštevníkov, aby sa zapísali do e-mailového zoznamu. Ak firmy používajú ako prihlasovacie miesto svoju web stránku, po prihlásení sa okamžite zašle prihlasovatel'ovi správa o tom, že sa prihlásil.

- Potvrdené prihlasovanie - predstavuje prísnejší spôsob získavania povolení, pre posielanie reklamných e-mailov. V tomto prípade sa vyžaduje od prihlasovatel'a odpovedat' na potvrdzovacie e-maily, bud' kliknutím alebo preposlaním e-mailu na potvrdenie prihlásenia. Iba tí prihlasovatelia, ktorí urobia tento krok, budú pridaní do zoznamu. 


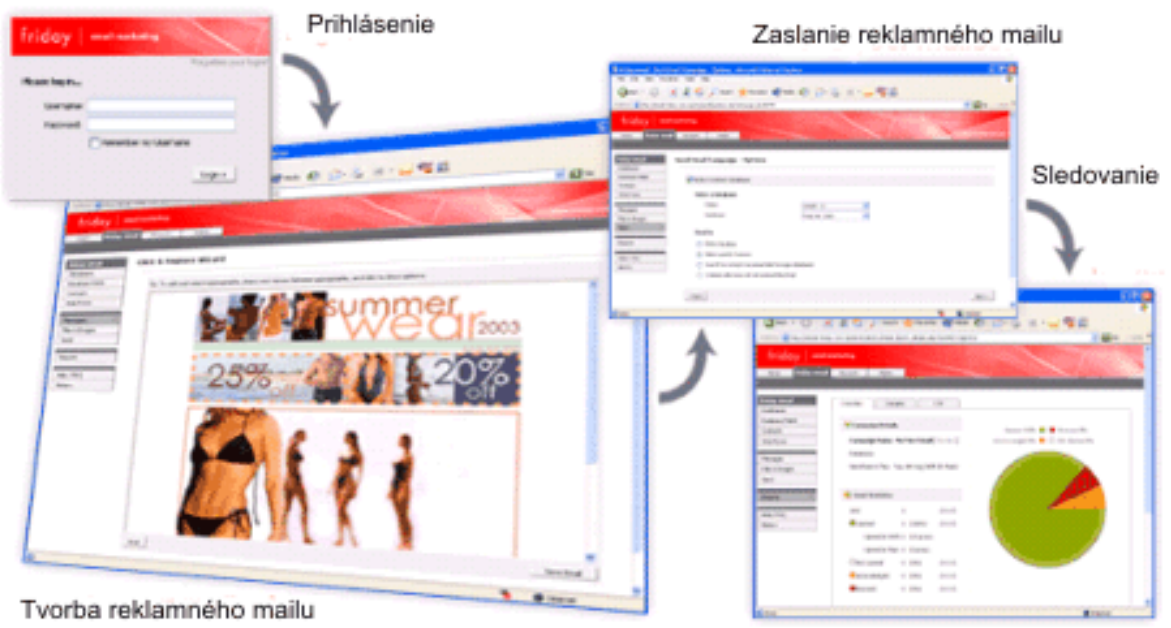

Obr.1 Príklad jednoduchého e-mail marketingového systému - www.friday.com.au

\subsection{Systém OPT-OUT}

Je opakom systému OPT-IN. Zasielatel' reklamných e-mailov tu zasiela obchodné ponuky aj napriek tomu, že vopred nezískal od príjemcu súhlas. Tento spôsob je však možné podl'a súčasnej legislatívy označit' za SPAM, aj ked' je tu možnost', že príjemca môže kedykol'vek toto odoberanie zrušit'.

Systém OPT-OUT sa však vel'mi často používa v spolupráci so systémom OPT-IN. Pri tejto kombinácii systémov si adresát reklamnej správy, okrem jednoduchého prihlásenia k odoberaniu reklamných informácií (OPT-IN), môže taktiež jednoducho d’alší odber reklamných správ zrušit' (OPT-OUT).

\section{Spôsoby použitia e-mailového marketingu}

Spôsobov využitia potenciálu e-mailového marketingu je mnoho. Nástroje je vždy potrebné prispôsobit' daným ciel'om a podmienkam kampane.

Najčastejšími formami rozosielania informácií sú [3]:

- jednorazový e-mail,

- spravodajca (newsletter),

- e-mailový časopis,

- Event-triggered e-mail.

\subsection{Jednorazový e-mail}

Jedná sa o jednorazové oslovenie skupiny užívatel'ov pomocou e-mailovej správy, čo predstavuje najjednoduchšiu formu použitia e-mailového marketingu. Výsledkom je emailová správa, ktorá má bud' textovú alebo grafickú podobu. Správa môže obsahovat' odkazy, obrázky, prílohy, formuláre, personalizovanú čast' a d’alšie prvky.

Takéto jednorazové oslovenie je možné použit’ při špeciálnych neopakujúcich sa akciách. Ciel'om býva informovanie užívatel'a, upútanie pozornosti alebo jeho konkrétna akcia.

\subsection{Spravodajca (newsletter)}

Pre budovanie vzt'ahu a pravidelnú komunikáciu so zákazníkmi je možné použit' tzv. informačného spravodajcu (newsletter).

Newsletter je pravidelne zasielaná formátovaná e-mailová správa. Užívatel' je zvyknutý, že dostáva nové informácie, upozornenia na špeciálne ponuky, zl'avy alebo 
aktuality pravidelne každý mesiac, prípadne $\mathrm{s}$ inou periodicitou. Vhodná frekvencia odosielania newsletteru je v intervale 2 až 6 týždňov. Dôležité je, aby správy naplnili očakávania užívatel’a a obsahovali hodnotné informácie. V opačnom prípade totiž hrozí, že užívatel' na spravodajcu zanevrie a prestane ho otvárat'. V krajnom prípade sa dokonca odhlási z jeho odberu. Pre budovanie dlhodobého vzt'ahu s užívatel'om je dobré použit' personalizáciu pri formátovaní a pri tvorbe samotného obsahu správy. Ciel'om newsletteru je získanie dôvery a upútanie pozornosti užívatel'a. Percento je čítanosti sa pohybuje medzi 20$50 \%$. Podl'a štatistík spoločnosti DoubleClick dostáva 57\% užívatel'ov e-mailové obchodné ponuky z elektronických obchodov a 55\% dostáva e-mailové obchodné ponuky z kamenných obchodov.

Výhody tejto formy e-mail marketingu:

- lacný,

- rýchly,

- l’ahko dostupný.

Vd'aka vysokej miere prekliknutia (CTR - Click Through Rate) patrí k najefektívnejším formám internetovej reklamy. Pomocou newslettrov sa buduje dlhodobý vzt'ah so zákazníkom. Podl'a prieskumu eMarketer.com je dôvera k tejto forme marketingu vel'mi vysoká, newslettrom dôveruje cca. $66 \%$ respondentov.

\subsection{E-mailový časopis}

Previazanost' e-mailového marketingu na vydávanie firemných elektronických alebo tlačených časopisov, zvýši samotnú efektivitu časopisu, pričom sa sprístupnia informácie väčšiemu okruhu užívatel'ov a tým sa l'ahšie získa ich pozornost'. E-mailová verzia časopisu obvykle obsahuje anotácie najdôležitejších článkov, obsah čísla a odkazy na internetovú verziu.

Ciel'om e-mailového časopisu je upozornit' užívatel'a na nové číslo, priviest' ho na stránky časopisu a informovat' ho o najdôležitejších novinkách. Pokial' existuje časopis v tlačenej podobe, pomocou e-mailového časopisu je možné získat' d'alší komunikačný kanál, ktorý je pre čast' užívatel'ov pohodlnejší, rýchlejší a umožňuje l'ahko získat' spätnú väzbu.

\subsection{Event-triggered e-mail}

Ide o účinnú reklamnú informáciu rozosielanú ako podporu $\mathrm{k}$ akcii v nadväznosti na nejakú udalost'.

Reklamná informácia má samozrejme vyššiu účinnost', pokial' ju užívatel' dostane v správny čas. Najlepšie tesne po uskutočnení nejakej akcie (objednávka, dopyt, prihlásenie sa k odberu noviniek). Užívatel' má totiž v čerstvej pamäti svoj záujem a ten sa odrazí aj v záujme o obsah zaslanej správy. Niektoré zahraničné štúdie uvádzajú výsledky prieskumov, z ktorých vyplýva, že vo všeobecnej populácii až $74 \%$ príjemcov si otvorí a prečíta túto správu pokial' im je doručená v priebehu jednej hodiny. $Z$ toho vyplýva, že čas je kritickým faktorom pre úspech takejto formy oslovenia [5].

Ako náhle vieme, že úspešnost' týchto event-triggered emailov je vysoká, je nutné sústredit' sa aj na ich kontext, ktorého obsahom môže byt' napríklad podpora značky, snaha o predaj čo najväčšieho množstva určitého tovaru, upozornenie a nasmerovanie užívatel'a na určitú lokalitu alebo podpora vzt'ah s ním. Užívatel’ovi sú na základe informácií, ktoré firme poskytol, automaticky zasielané informačné e-maily. Príkladom môže byt' aj prianie k narodeninám alebo sviatku. Tento druh správ sa bežne používa i v obchodnej komunikácii. Napríklad pokial' firma vie, že jej klient je vlastníkom nejakého výrobku, dostáva automaticky a v pravý čas informácie o jeho doplnkoch, vlastník nového auta môže po 12 mesiacoch 
automaticky obdržat' pozvánku k servisnej prehliadke automobilu, majitel' mobilného telefónu môže obdržat' dva týždne od nákupu špeciálnu ponuku na sadu hands-free a pod.

Ciel'om event-triggered správ je podnietit' užívatel'a ku konkrétnej akcii. Súčast'ou emailu môže byt' objednávka alebo aspoň odkaz na internetovú prezentáciu s objednávkou. Efektivita takýchto e-mailov je značne vysoká a pohybuje sa medzi 10-15\% v závislosti od typu ponuky.

\section{Záver}

E-mailový marketing predstavuje jednu z expandujúcich oblastí internetového marketingu. Jeho prednost’ami sú nákladová nenáročnost' a relatívne vysoká efektivita. Čo však čiastočne brzdí jeho d’alší rozvoj je častá a mylná zámena zasielaných reklamných informácií so SPAM-om, z čoho pramení jeho negatívna akceptácia na strane adresáta. V prípade jasnej a jednoznačnej implementácie jedného zo systémov emailového marketingu (opt-in, opt-out) je možné tento problém odstránit' a tým zaručit' akceptáciu vyžiadaných reklamných správ adresátmi.

\section{Literatúra}

[1] ČOREJOVÁ, T., MAJERČÁKOVÁ, M.: K vybraným problémom postavenia zákazníka na info-komunikačných trhoch, In: Globalizácia a jej sociálno-ekonomické dôsledky '04 : zborník príspevkov z medzinárodnej vedeckej konferencie : I. čast' : 6.-7. október 2004, Rajecké Teplice, Slovenská republika. - Žilina: Žilinská univerzita, 2004. - ISBN 808070-310-8. - S. 70-74.

[2] KREMEŇOVÁ, I., ROSTÁŠOVÁ, M..: Marketing v službách, Marketingový informačný systém, EDIS, ŽU v Žiline, 2006, ISBN 80-8070-358-2

[3] MADLEŇÁK, R.: Analýza foriem internetovej reklamy - e-mailová reklama, In: Pošta, Telekomunikácie a Elektronický obchod: elektronický odborný časopis zameraný na problematiku poštových a telekomunikačných podnikov a oblast' elektronického obchodovania. - ISSN 1336-8281. - Roč. 1, č. 3 (2006), s. 28-33.

[4] MADLEŇÁKOVÁ, L.: K problematike hodnotenia spokojnosti zákazníka, In: POSTPOINT 2005 : medzinárodná konferencia zástupcov poštových správ a univerzít. Katedra spojov, ŽU Žilina, 2005, ISBN 80-8070-454-6. - S. 148-153

[5] PRŮŠA, P.; DRAHOTSKÝ, I. Marketing dodavatelských vztahů v době internetu. Nákupní procesy B2B v dalším tisíciletí. 2004. Pardubice..

[6] VACULÍK, J.: Marketing v prostredí internetu, In: Zborník príspevkov z medzinárodnej vedeckej konferencie KIT 2003 - Komunikačné a informačné technológie : 26.-28. novembra 2003 Jánska Dolina, Liptovský Mikuláš. - V Liptovskom Mikuláši: Vojenská akadémia, 2003. - ISBN 80-968711-4-5. - S. 7-11.

\section{Grantová podpora}

I14-07-140 Príležitosti a hrozby e-mailovej komunikácie

MVTS Bil/Nem/SR/ŽU/06 Pravidlá dodržiavania sút'aže na trhu elektronických komunikácií

1/4573/07 VEGA MŠ SR a SAV - Možnosti, ohraničenia a vývojové tendencie koncepcie univerzálnej služby v pošte a telekomunikáciách v procese globalizácie

1/2591/05 VEGA MŠ SR a SAV - Vplyv výberu efektívnej stratégie na udržiavanie konkurencie schopnosti podniku v rámci liberalizácie poštových trhov 